\title{
IMPACTS OF MACROECONOMY ON STOCK MARKET: EVIDENCE FROM PAKISTAN
}

\author{
Farid Ullah $^{1}$--- Ijaz Hussain ${ }^{2}$--- Abdur Rauf ${ }^{3}$ \\ ${ }^{1,2}$ Muhammad Ali Jinnah University, Islamabad \\ ${ }^{s}$ Gomal University, D.I.Khan
}

\begin{abstract}
Stock market is a place where the securities of listed companies are traded and this can be affected by both macroeconomic and non-macroeconomic factors. The impacts of macroeconomic factors on stock market of Pakistan are investigated in the current study. For this purpose monthly data covering the period from January 2008 to December 2012 is used in this study while taking the three most important macroeconomic variables, Exchange Rate, Interest Rate and Inflation. Using the more advance Bound Testing Approach, a very strong long run cointegration is found amongst the variables taken for the study. In the long span of time, the results suggest that both Exchange Rate and Interest Rate have negative association with stock market of Pakistan while the Inflation Rate does not create such a condition that affect the stock market of Pakistan. Same results are found for the shorter version of time.
\end{abstract}

Keywords: Exchange rate, Interest rate, Inflation, Stock market.

Received: 9 September 2013/ Revised: 30 December 2013/ Accepted: 10 January 2014/ Published: 22 January 2014

\section{INTRODUCTION}

The stock exchange is the place where securities (shares) of listed companies are traded. Investment (foreign \& domestic) is made through stock exchange. The prime objective of the investors is to earn profit on their investments in form of dividend or increases in stock prices. So, stock exchange is very important for the economy of any country. Stock exchange performance is influences by many factors like macroeconomic and non-macroeconomic variables. Hussain and Ngoc (2009) are of the view that domestic and international indicators have some impact on stock prices. Stock market can be affected by various factors especially the macroeconomic variables, e.g. inflation in a country, exchange rates, Money injected to the market and Risk Premium, (Rjoub et al., 2009).

The Efficient Market theory suggests that there are three possibilities regarding the performance of the stock market, 1- there is no impacts of any news on stock market, 2- some 
news can affect the performance of stock market and 3-all types of news affect the performance of stock market ${ }^{1}$.

Various empirical studies can be found investigated the performance of the stock market such as; there is insignificant relationship between stock exchange and macroeconomic variables (Sharma and Mahendru, 2010). Inflation has negative correlation with the stock market of Pakistan (Akbar et al., 2012). Inflation rate significantly explain the expected average stock return (Bodurtha et al., 1989). Change in inflation has no impact on stock prices (Osemi and Nwisa, 2011). Inflation rate is not consistent with stock prices (Hardouvelis, 1987). Positive relationship exists between stock market and inflation rate in the US economy (Ratanapakorn and Sharma, 2007). Similarly vast literature is found which analyzed the interest rate and stock market relationship, e.g. that interest rate has no significant effect on stock market (Seiler et al., 1998). Interest rate is correlated with stock market index (Demange and Laroque, 1999). There is no causal relationship between Indian stock prices and interest rate (Bhattacharya and Mukherjee, 2003). Increase in interest rate decrease stock market return (Lunde and Timmermann, 2004). Stock returns are significantly influenced by changes in interest rate (Rehman and Mohsin, 2011). Exchange rates can also have significant impacts on stock market, e.g. depreciation of money change the whole pattern of the stock market (Hondroyiannis and Papaetrou, 2001). Exchange rate and stock market return are significantly linked with one another (Tai, 2010). Exchange rate and stock market return do not have a significant long run relationship (Zia and Rahman, 2011). There is no relationship between exchange rate and KSE 100 index (Ali et al., 2010).

Current study is an attempt to find that whether the macroeconomic variation in the economy of Pakistan have any impacts on stock market of Pakistan? Karachi Stock Exchange (KSE-100 index), being the largest stock exchange of Pakistan, is taken for the analysis. Positive correlation is assumed between the stock exchange of Pakistan and the macroeconomic fluctuation in the economy. Rest of the paper is organized as following, the second section discuss the data and methodology, the results interpretation and conclusion are discussed in the third and fourth sections respectively.

\section{DATA AND METHODOLOGY}

\subsection{Data}

To cover the period from January 2008 to December 2011, monthly data is used for the analysis. Various issues of Economic Survey of Pakistan are consulted for collecting the data on Consumer Price Index, Data on interest rate is collected from State bank of Pakistan, Onda .com is consulted for Exchange Rate and the official Web of Karachi Stock Exchange is consulted for data on this particular variable.

\footnotetext{
${ }^{1}$ These are the three hypothesis of the Efficient Market Theory, first one is called weak hypothesis, second semi-strong and third strong hypothesis. Karachi Stock Exchange is a semi efficient market.
} 


\subsection{Methodology}

Relatively more advance technique is applied in the current study, the Bound Test Approach which is develop by Pesaran et al. (2001), and Pesaran and Shin (1999). It gives effective result even at small sample size. It estimates short run elasticity's without damaging long run results. In case where the variable has second order of integration then this approach cannot be used.

Our simple econometric model is as;

$$
\ln K S E_{t}=\beta 0+\beta 1 \ln E R t+\beta 2 \ln C P I t+\beta 3 \ln I R t+\mu t
$$

$\ln \mathrm{KSE}=$ natural $\log$ of KSE 100 index.

$\ln \mathrm{ER}=$ natural $\log$ of Exchange rates.

$\ln \mathrm{CPI}=$ natural $\log$ of Consumer price index.

$\ln \mathrm{IR}=$ natural $\log$ of interest rate.

Bound test approach, usually conducted in three steps, a- analyzing the long run cointegration where the decision is made on the basis of the Wald F-statistics, in case the calculated value of the F-statistic is greater than the tabulated value of the F-statistics at $5 \%$ level of significance then there is long run cointegration and vice versa. In the second, once it is known that the long run cointegration existed, the magnitude of the long run elasticities is estimated and in the third and final step the short run dynamics are extracted from the long run elasticities.

The general form of the approach is

$\Delta \mathrm{Zt}=\alpha_{0}+\alpha_{1}+\Pi Z_{\mathrm{t}-1}+\Sigma \Gamma j \Delta \mathrm{Z}_{\mathrm{t}-1}+\varepsilon \mathrm{t}+$

Here $\Pi$ and $\Gamma j$ are matrices representing the long run and short run multipliers, on the basis of this equation our estimated model are,

$\Delta \operatorname{lnKSEt}=\propto 0+\sum_{\mathrm{i}=1}^{\mathrm{p}} \alpha 1 \Delta \ln K S E t-\mathrm{i}+\sum_{\mathrm{i}=1}^{\mathrm{q}} \alpha 2 \Delta \ln E R \mathrm{t}-\mathrm{i}+\sum_{\mathrm{i}=1}^{\mathrm{r}} \alpha 3 \Delta \ln C \mathrm{PIt}-$ $\mathrm{i}+\sum_{\mathrm{i}=1}^{\mathrm{s}} \alpha 4 \Delta \ln I R \mathrm{t}-\mathrm{i}+\mathrm{v} \operatorname{lnKSEt}-1+\mathrm{O}^{\prime} \ln E R \mathrm{t}-1+\theta \ln \mathrm{CPIt}-1+\mathrm{Q} \ln I R \mathrm{R}-$ $1+\varepsilon \mathrm{t}--------i i$

Here in this model $\alpha 1, \alpha 2, \alpha 3, \alpha 4$, represents the short run dynamics whileU, $\mathbf{O}^{\prime}, \boldsymbol{\theta}, \boldsymbol{Q}$, represents long run effects in the model.

For long run coefficient we estimate following model,

$\operatorname{lnKSE}=\alpha 0+\alpha 1 \ln E R t-1+\alpha 2 \operatorname{lnCPIt}-1+\alpha 3 \ln I R t-1+\varepsilon t-{ }_{-}-$-_-iii $_{-}$

Short run dynamics are estimated through,

$$
\begin{aligned}
\Delta \ln K S E & =\alpha 0+\sum_{i=1}^{\mathrm{p}} \alpha 1 \Delta \mathrm{ERt}-\mathrm{i}+\sum_{\mathrm{i}=1}^{\mathrm{q}} \alpha 2 \Delta \ln \mathrm{CPIt}-\mathrm{i}+\sum_{\mathrm{i}=1}^{\mathrm{r}} \alpha 3 \Delta \ln \operatorname{lRt}-\mathrm{i}+\varepsilon \mathrm{t} \\
----\mathrm{iv} &
\end{aligned}
$$




\section{RESULTS INTERPRETATION}

\subsection{Unit Root Test}

Stationarity of data has been tested through Augmented Dickey Fuller (ADF) and Philip Perron test (PP). Table (1) shows that dependent (KSE) is stationary at first difference both in $\mathrm{ADF}$ and PP test, exchange rate and interest rate are stationary at level while inflation which has been represented by CPI is stationary at first difference. As all variables are stationary at $I(1)$ and $I(0)$, Therefore we can move forward for Bound testing approach

Table-1. Unit Root Test

\begin{tabular}{lllll}
\hline Variables & ADF $($ Level $)$ & ADF $\left(\mathbf{1}^{\text {st }}\right.$ diff $)$ & PP $($ Level $)$ & PP $\left(\mathbf{1}^{\text {ST }}\right.$ diff $)$ \\
\hline $\ln \mathrm{KSE}$ & -1.718837 & -5.614925 & -1.823518 & -5.594994 \\
\hline $\ln \mathrm{ER}$ & -3.730285 & -6.292884 & -3.328800 & -6.394769 \\
\hline $\ln \mathrm{CPI}$ & -0.877674 & -4.815370 & -1.541165 & -4.994584 \\
\hline $\ln \mathrm{R}$ & -4.658022 & -6.640567 & -2.871057 & -6.682129 \\
\hline
\end{tabular}

Critical Value (5\%): -2.9251 and -2.9266

Table-2. Bound Test Result for Co-integration

\begin{tabular}{lll}
\hline \multicolumn{3}{c}{ F-Statistic $=\mathbf{8 . 1 8 4 0}$} \\
\hline At $(5 \%)$ & Lower Bound Value & Upper Bound Value \\
\hline
\end{tabular}

The lower and upper bound values are taken from Pesaran et al. (2001)

Above table (2) shows that $\mathrm{F}$ calculated value is greater than $\mathrm{F}$ tabulated hence long run cointegration exist between variables and we can go forward for long run coefficient estimation and error correction model. So hypothesis of no co-integration is rejected and alternate is accepted.

Table-3. Long run coefficient ARDL $(1,0,0,0)$ on SIC Dependent Variable: $\ln \mathrm{KSE}$

\begin{tabular}{lllll}
\hline Regressors & Coefficient & Std-error & T-ratio & Prob \\
\hline $\ln \mathrm{ER}$ & -2.0116 & .9111 & -2.2079 & .033 \\
\hline $\ln \mathrm{CPI}$ & -.1049 & .2268 & -.4622 & .646 \\
\hline $\ln \mathrm{IR}$ & -1.2778 & .6092 & -2.0974 & .042 \\
\hline $\mathrm{C}$ & 21.1667 & 3.2504 & 6.5120 & .000 \\
\hline $\mathrm{T}$ & .0182 & .0056 & 3.2995 & .002 \\
\hline
\end{tabular}

Table-4. Error Correction Model ARDL(1,0,0,0 ) on SICDependent variable: $\mathrm{d} \ln \mathrm{KSE}$

\begin{tabular}{lllll}
\hline Regressors & Coefficient & Std-error & T-ratio & Prob \\
\hline $\mathrm{d} \ln \mathrm{ER}$ & -.6972 & .4106 & -1.6980 & .097 \\
\hline $\mathrm{d} \ln \mathrm{CPI}$ & -.0364 & .0733 & -.4963 & .622 \\
\hline $\mathrm{d} \ln \mathrm{R}$ & -.4429 & .2539 & -1.7446 & .089 \\
\hline $\mathrm{d} \mathrm{C}$ & 7.3359 & 2.6196 & 2.8004 & .008 \\
\hline $\mathrm{d} \mathrm{T}$ & .0063 & .0031 & 2.0900 & .043 \\
\hline $\mathrm{ecm}(-1)$ & -.3466 & .1051 & -3.2977 & .002 \\
\hline
\end{tabular}

R-square $=.3162$ R-Bar square $=.2362 \quad$ D.W $=1.65$ 
Table (3) represents long run relationship between Macroeconomic Variables and Stock Market. It is clear from the table that exchange rate and interest rate shows negative relationship with stock market in long run. These results support the study of (Hasan and Javed, 2009). Inflation has negative but insignificant impact on stock market. Sharma and Mahendru (2010), Osemi and Nwisa (2011) also provided same results. The value of trend is positive and significant. This suggests that stock market with the passage of time perform well.

The extracted short run dynamics are displayed in Table (4) which shows that both exchange rate and interest rate hinder the performance of stock market of Pakistan in the short run as well. The inflation rate remains insignificant here too. We got the expected negative sign for ECM which shows a moderate speed of adjustment. It is suggested by the Error Correction Mechanism that almost $34 \%$ disequilibrium is adjusted from the previous year shock to equilibrate with the long run equilibrium.

The diagnostic test suggested that there is no detection of serial correlation and heteroscadasticity and also the model is well specified having no problem with normality. Stability of the model is suggested by CUSUM and CUSUMSQ.

Table-5. Diagnostic test LM version:

\begin{tabular}{cccc}
\hline & Test Statistic & Chi -Square & Value \\
\hline A- & Serial Correlation & $\chi^{2}$ & $1.0416(.307)$ \\
\hline B- & Functional Form & $\chi^{2}$ & $1.3932(.163)$ \\
\hline C- & Normality & $\chi^{2}$ & $2.6295(.269)$ \\
\hline D- & Heteroscadasticity & $\chi^{2}$ & $1.2686(.147)$ \\
\hline
\end{tabular}

A: LM Test, B: Ramsey's RESET Test, C: JB Test and D: White Test

Figure-1. CUSUM and CUSUMSQ

Plot of Cumulative Sum of Recursive Residuals



Figure-2.

Plot of Cumulative Sum of Squares of Recursive Residuals






\section{CONCLUSION}

This paper investigates the impact of Macroeconomy on stock market. Monthly data has been collected from different sources for exchange rates, inflation, interest rate and stock market. The results of this study conclude that the relationship between macroeconomic factors and stock market is more or less same as practiced in the rest of world. By using bound testing approach it is clear that increase in exchange and interest rate reduce the performance of stock market both in long and short run. On the other hand inflation shows no significant relationship with stock market both in short and long run. Thus the government in light of the findings of this study should handle the interest rate and exchange rate carefully to enhance the performance of Stock Market.

Funding : This study received no specific financial support.

Competing Interests: The authors declare that they have no conflict of interests.

Contributors/Acknowledgement: All authors contributed equally to the conception and design of the study.

\section{REFERENCES}

Akbar, M., S. Ali and M.F. Khan, 2012. The relationship of stock prices and macroeconomic variables revisited: Evidence from Karachi stock exchange. African Journal of Business Management, 6(4): $1315-1322$.

Ali, I., K. Rehman, A.K. Yilmaz, M.A. Khan and H. Afzal, 2010. Casual relationship between macroeconomic indicators and stock exchange prices in Pakistan. African Journal of Business Management, 4(3): 312-319.

Bhattacharya, B. and J. Mukherjee, 2003. The nature of the causal relationship between stock market and macroeconomic aggregates in India. Paper Presented at the Fifth Annual Conference on Money and Finance in the Indian Economy on January.

Bodurtha, J.N., C. Cho and L.W. Senbet, 1989. Economic forces and stock market: An international perspective. The Global Finance Journal, 1(1): 2 1-46.

Demange, G. and G. Laroque, 1999. Efficiency and options on the market index. Economic Theory, 14(1): $227-235$.

Hardouvelis, G.A., 1987. Macroeconomic information and stock prices. Journal of Economic and Business, 39(2): 131-140.

Hasan, A. and M.T. Javed, 2009. Macroeconomic influences and equity market returns: A study of an emerging equity market. Journal of Economic Education Research, 10(2): 47-68.

Hondroyiannis and Papaetrou, 2001. Macroeconomic influences on the stock market. Journal of Economics and Finance, 25(1): 33-49.

Hussain, K. and L.K. Ngoc, 2009. The impact of macroeconomic indicators on vietnam stock prices. Journals of Risk Finance, 10(4): 221-332

Lunde, A. and A. Timmermann, 2004. Duration dependence in stock prices: An analysis of bull and bear markets. Journal of Business and Economic Statistics, 22(3): 253-273. 
Osemi, I.O. and P.I. Nwisa, 2011. Stock market volatility and macroeconomic variables volatility in Nigeria. European Journal of Business and Management, 3(12): 43-53.

Pesaran, M.H. and Y. Shin, 1999. An autoregressive distributed lag approach to cointegration analysis, in econometric and economic theory in the twentiethcentury. Cambridge: Cambridge University Press.

Pesaran, M.H., Y. Shin and R.J. Smith, 2001. Bounds testing approaches to the analysis of level relationships. Journal of Applied Econometrics, 16(3): 289-326.

Ratanapakorn, O. and C. Sharma, 2007. Dynamic analysis between the US stock returns and the Macroeconomic variables. Applied Financial Economics, 17(5): 369-337.

Rehman, H. and H.M. Mohsin, 2011. Monetary policy announcements and stock returns: Evidence from the Pakistani market. Transit Stud Rev., 18(2): 342-360.

Rjoub, H., T. Turgut and N. Gunsel, 2009. Effects of macroeconomic factors on stock returns. Studies in Economic and Finance, 26(1): 36-45.

Seiler, M.J., P. Shyu and Sharma, 1998. Do changes in the discount rate and fed funds rate affects financial market returns? Managerial Finance, 27(8): 16-25.

Sharma, G.D. and M. Mahendru, 2010. Impact of macroeconomic variables on stock prices in India. Global Journal of Management and Business Research, 10(7): 19-26.

Tai, C.S., 2010. Foreign exchange risk and risk exposure in the Japanese stock market. Managerial Finance, 36(6): 511-524.

Zia, Q.Z. and Z. Rahman, 2011. The causality between stock market and foreign exchange market of Pakistan. Interdisciplinary Journal of Contemporary Research in Business, 3(5): 906-919 